\title{
MODIFIKASI LARUTAN BUAH BIT (Beta vulgaris $L$.) SEBAGAI ALTERNATIF PENGGANTI ZAT WARNA EOSIN 2\% PADA PEMERIKSAAN TELUR CACING STH (Soil Transmitted Helminths)
}

\author{
Modification Of Beetroot Solution (Beta vulgaris L.) As An Alternative \\ To 2\% Eosin In The Examination Of STH (Soil Transmitted Helminths) Eggs
}

\author{
Benediktus Adventhia Daeli ${ }^{\text {* }}$ \\ Fepy Yulianti ${ }^{2}$ \\ Karolina Rosmiati ${ }^{3}$ \\ *IAkademi Kesehatan John Paul II \\ Pekanbaru \\ 2Akademi Kesehatan John Paul II \\ Pekanbaru \\ ${ }^{3}$ Akademi Kesehatan John Paul II \\ Pekanbaru \\ * email: karolina.rosmiati@akjp2.ac.id
}

\section{Kata Kunci:}

Buah Bit (Beta vulgaris $L$ )

Cacing STH

Eosin 2\%

Modifikasi

\section{Keywords:}

Beetroot (Beta vulgaris $L$ )

STH Worm

2\% Eosin

Modification

\begin{abstract}
Abstrak
Menurut data World Health Organization (WHO) pada tahun 2018 menyatakan $24 \%$ dari populasi dunia terinfeksi oleh Soil Transmitted Helminths (STH). Cacing golongan ini memerlukan tanah untuk menjadi bentuk yang infektif. Eosin $2 \%$ merupakan zat warna yang digunakan dalam pemeriksaan telur cacing. Buah bit (Beta vulgaris L.) adalah salah satu flora yang banyak digunakan sebagai pewarna alami. Buah bit mengandung betasianin yang menghasilkan pigmen berwarna merah. Tujuan penelitian ini untuk mengetahui kemampuan buah bit menggantikan peran eosin dalam mewarnai telur cacing. Penelitian ini dilakukan secara true eksperimental dengan desain static group comparison. Setelah dilakukan penelitian didapatkan hasil yang menunjukkan konsentrasi larutan buah bit yang memiliki kualitas sama dengan eosin $2 \%$ adalah larutan buah bit konsentrasi $95 \%$. Larutan konsentrasi $95 \%$ menghasilkan kualitas warna dengan latar belakang kontras, sehingga morfologi telur dapat terilhat jelas. Larutan buah bit tahan selama penyimpanan 7 hari pada suhu dingin.
\end{abstract}

\begin{abstract}
Helminthiasis is one of the infections caused by parasites. World Health Organization (WHO) data in 2018 reported 24\% of the world's population was infected by Soil Transmitted Helminths (STH). Worms of this group need soil to be in their infective stage. Eosin $2 \%$ is a stain used in the examination of worm eggs. Beetroot (Beta vulgaris L.) is one of the plants widely used as a natural dye. Beetroot contains betacyanin which produces red pigment. The purpose of this study was to identify the feasibility of beetroot as a substitute of eosin to stain worm eggs. This research was true experimental with static group comparison design. The results showed that the concentration of beetroot solution propotional to the quality of $2 \%$ eosin is with a concentration of $95 \%$. Beetroot solution produces color quality with a contrasting background, so that the morphology of eggs can be clearly observed. Beetroot extract lasts for 7-day storage at cold temperature.
\end{abstract}

\section{PENDAHULUAN}

Kecacingan merupakan masalah kesehatan yang paling banyak ditemukan di dunia. Menurut data World Health Organization (WHO) pada tahun 2018 menyebutkan bahwa lebih dari I,5 miliar orang atau $24 \%$ dari populasi dunia terinfeksi oleh Soil Transmitted Helminth (STH) (Subair et al., 2019). Prevalensi penyakit kecacingan di Indonesia masih tergolong tinggi terutama pada anak-anak sekolah dasar dan penduduk miskin dengan sanitasi yang buruk, tidak memiliki jamban dan fasilitas air bersih yang kurang, kebersihan kuku, dan kebiasaan jajan di sembarang tempat (Rezki \& Aritonang, 2018).

Salah satu cara mendiagnosa penyakit kecacingan, adalah dengan melakukan pemeriksaan mikroskopis. Pemeriksaan secara mikroskopis biasanya menggunakan mikroskop dengan pewarnaan eosin $2 \%$. Eosin $2 \%$ dapat mewarnai telur cacing karena reagen ini bersifat asam dan berwarna merah jingga (Oktari \& Mu'tamir, 2017). Reagen Eosin 2\% ditinjau dari ekonomi tergolong mahal dan eosin merupakan bahan 
kimia yang tidak ramah lingkungan maka perlu dilakukan pengembangan metode menggunakaan bahan alam yang lebih ramah lingkungan dan harga yang lebih terjangkau. Salah satu bahan alam yang dapat digunakan sebagai pewarna alami yang memiliki sifat sama dengan eosin adalah buah bit (Beta vulgaris L.).

Buah bit (Beta vulagaris L.) merupakan salah satu bahan pangan yang bermanfaat sebagai pewarna alami pada pembuatan produk pangan, namun belum banyak digunakan dalam bidang kesehatan. Pigmen yang terdapat dalam buah bit merah adalah betasianin. Betasianin merupakan pigmen berwarna merah atau violet yang merupakan kelompok dari flavonoid bersifat polar (Novatama \& Kusumo, 20I4).

\section{METODE PENELITIAN}

Penelitian ini bersifat true eksperimental dengan desain static goup comparison yaitu suatu kelompok dikenakan perlakuan tertentu, kemudian diamati perbedaan hasil pewarnaan pada feses yang mengandung telur cacing STH.

Sampel yang digunakan adalah larutan buah bit konsentrasi 65\%, 80\% dan 95\%. Penelitian ini dilakukan di Laboratorium Parasitologi Akademi Kesehatan John Paul II Pekanbaru.

\section{Alat dan Bahan}

Alat yang digunakan dalam penelitian ini yaitu pisau, spatula, corong, Mikroskop, Object glass, deck glass, pipet tetes, botol wadah ekstrak bit, Erlenmeyer $25 \mathrm{ml}$, gelas ukur glass $100 \mathrm{~mL}$, kertas $\mathrm{pH}$, tissue.

Bahan yang digunakan dalam penelitian ini yaitu larutan buah bit konsentrasi $65 \%, 80 \%, 95 \%$, etanol $96 \%$, Eosin $2 \%$, dan feses positif telur cacing STH.

\section{Cara Kerja}

\section{Pembuatan larutan buah bit dan penyimpanan}

\section{Larutan buah bit $65 \%$}

Buah bit Ditimbang $6.5 \mathrm{gr}$, kemudian digerus menggunakan mortal dan alu. Dilarutkan menggunakan $10 \mathrm{~mL}$ etanol $96 \%$.

\section{Larutan buah bit $\mathbf{8 0 \%}$}

Buah bit ditimbang $8 \mathrm{gr}$, kemudian digerus menggunakan mortal dan alu. Dilarutkan menggunakan $10 \mathrm{~mL}$ etanol $96 \%$.

\section{Larutan buah bit $95 \%$}

Buah bit ditimbang $9.5 \mathrm{gr}$, kemudian digerus menggunakan mortal dan alu. Dilarutkan menggunakan IOmL etanol $96 \%$.

\section{Penyimpanan Larutan buah bit}

Buah bit yang telah di larutan di simpan pada suhu ruang $\left(25^{\circ} \mathrm{C}\right)$ dan suhu dingin selama 7 hari, 14 hari, dan 2 I hari.

\section{Pembuatan Preparat Telur STH dengan Ekstrak buah bit}

Larutan buah bit diteteskan I-2 tetes pada kaca objek, kemudian feses diambil dengan stick dan dicampurkan dengan ekstrak buah bit sampai homogen, kemudian diperiksa di bawah mikroskop cahaya menggunakan lensa objektif dengan perbesaran IOX dan 40X.

\section{HASIL DAN PEMBAHASAN HASIL}

Berdasarkan hasil penelitian, proses penggunaan larutan buah bit sebagai pewarna alternatif pada pemeriksaan telur cacing yang menggunakan perlakuan variasi konsentrasi $65 \%, 80 \%$, dan 95 dengan kontrol dapat dilihat pada tabel 4.I

Tabel 4.I Hasil Pewarnaan telur cacing STH larutan buah bit dan kontrol

\begin{tabular}{|c|c|c|c|c|c|c|c|}
\hline & \multicolumn{7}{|c|}{ Hari dan Suhu } \\
\hline & \multirow{2}{*}{$\begin{array}{l}\text { Hari I } \\
\text { Suhu } \\
\text { Ruang }\end{array}$} & \multicolumn{2}{|c|}{ Hari ke-7 } & \multicolumn{3}{|c|}{ Harike-14 } & \multirow{2}{*}{$\begin{array}{l}\text { Hari } \\
\text { ke-2 }\end{array}$} \\
\hline & & $\begin{array}{l}\text { Suhu } \\
\text { Ruang }\end{array}$ & $\begin{array}{c}\text { Suhu } \\
\text { Ding } \\
\text { n }\end{array}$ & $\begin{array}{l}\text { Suhu } \\
\text { Ruang }\end{array}$ & $\begin{array}{l}\text { Suhu } \\
\text { Dingin }\end{array}$ & $\begin{array}{l}\text { Suhu } \\
\text { Ruang }\end{array}$ & \\
\hline $\begin{array}{c}\text { Kons } \\
\text { entra } \\
\text { si } \\
65 \% \\
\end{array}$ & I & - & - & - & - & - & - \\
\hline $\begin{array}{c}\text { Kons } \\
\text { entra } \\
\text { si } \\
80 \%\end{array}$ & 2 & - & - & - & - & - & - \\
\hline $\begin{array}{c}\text { Kons } \\
\text { entra } \\
\text { si } \\
95 \%\end{array}$ & 3 & 1 & 3 & - & 2 & - & I \\
\hline Eosin & 3 & 3 & 3 & - & 3 & - & 3 \\
\hline
\end{tabular}


$2 \%$

Keterangan :

Kriteria Penilaian :

I : Latar belakang tidak kontras, telur cacing tidak menyerap warna, bagian telur tidak terlihat

2 : Latar belakang kurang kontras, telur cacing kurang menyerap warna, bagian telur kurang jelas terlihat

3 : Latar belakang kontras, telur cacing menyerap warna, bagian telur terlihat jelas

- : Tidak dilakukannya pemeriksaan (Oktari \& Mu'tamir, 2017)

Tabel 4.2 Perbandingan kualitas pewarnaan menggunakan larutan buah bit berbagai konsentrasi dan kontrol

\begin{tabular}{|c|c|c|c|c|c|}
\hline No. & Ket. & $\begin{array}{l}\text { Eosin } \\
2 \%\end{array}$ & $\begin{array}{l}\text { Larutan } \\
65 \%\end{array}$ & $\begin{array}{l}\text { Larutan } \\
80 \%\end{array}$ & $\begin{array}{l}\text { Larutan } \\
95 \%\end{array}$ \\
\hline $\mathrm{I}$ & Hari I & & & & \\
\hline 2 & $\begin{array}{l}\text { Hari / ( } \\
\text { suhu } \\
\text { ruang) }\end{array}$ & & - & - & \\
\hline 3 & $\begin{array}{l}\text { Hari } 7 \\
\text { (suhu } \\
\text { dingin) }\end{array}$ & & - & - & \\
\hline 4 & $\begin{array}{l}\text { Hari I4 } \\
\text { (suhu } \\
\text { dingin) }\end{array}$ & & - & - & \\
\hline 5 & $\begin{array}{l}\text { Hari 2I } \\
\text { (suhu } \\
\text { dingin) }\end{array}$ & & - & - & 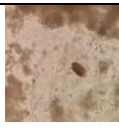 \\
\hline
\end{tabular}

\section{PEMBAHASAN}

Berdasarkan hasil penelitian yang disajikan pada tabel 4.2 menunjukkan bahwa perbandingan konsentrasi larutan buah bit memberikan kualitas pewarnaan yang berbeda terhadap kontrol. Berdasarkan Tabel 4.2 juga dapat dilihat kualitas pewarnaan yang paling mendekati kualitas kontrol (eosin 2\%) adalah larutan buah bit dengan konsentrasi 95\%. Untuk ketahanannya sendiri larutan buah bit konsentrasi $95 \%$ hanya tahan 7 hari dengan penyimpanan pada suhu dingin, pada hari ke 14 (suhu dingin) kualitas warna yang dihasilkan mengalamii penurunan kualitas yaitu latar belakang yang kurangkontras serta telur yang kurang menyerap zat warna, sehingga bagian telur kurang terlihat jelas. Kualitas larutan pada penyimpanan 12 hari (suhu dingin) didapatkan latar belakang yang tidak terwarnai, sehingga morfologi telur sulit untuk dilihat.

Penyimpanan larutan buah bit ini dibedakan menjadi dua yaitu menyimpan pada suhu dingin dan suhu ruang, gunanya untuk melihat ketahanan dari larutan ini sendiri. Penyimpanan larutan buah bit pada suhu ruang dan suhu dingin mengalami penurunan kualitas warna pada hari yang berbeda. Pada suhu dingin direkomendasikan hingga hari ke-7. Karena pada hari ke-7 warna yang dihasilkan masih baik, dengan latar belakang kontras dan morfologi telur terlihat jelas. Setelah penyimpanan lebih dari 7 hari kemampuan larutan buah bit untuk mewarnai sediaan mengalami penurunan, dapat dilihat pada hari ke 14 warna yang dihasilkan kurang kontras sehingga morfolgi telur kurang terlihat jelas. Pada hari ke 21 warna larutan buah bit sudah mengalami perubahan yaitu yang awalnya berwarna merah berubah menjadi kehijauan, sehingga latar belakang tidak terwarnai dan telur cacing sulit untuk ditemukan. Sedangkan penyimpanan pada suhu ruang selama 7 hari sudah mengalami kerusakan, larutan sudah tidak mampu lagi untuk mewarnai sediaan, latar belakang tidak terwarnai sama sekali, dan juga warna larutan sudah berubah dari merah menjadi kehijauan, maka sebaiknya setelah larutan buah bit dibuat langsung digunakan untuk pemeriksaan.

Ada beberapa keterbatasan dalam pemanfaatan larutan buah bit sebagai pewarna alami, salah satunya pigmen betasianin yang mudah sekali mengalami degenerasi. Degenerasi terjadi karena beberapa faktor seperti cahaya, oksigen, suhu, dan lingkungan sekitar seperti adanya besi, tembaga aluminum dan timah sehingga penyimpanan larutan buah bit harus berada dalam kondisi gelap dengan wadah yang tertutup. Penyimpanan maksimal larutan buah bit yaitu 7 hari dalam kondisi suhu dingin, karena penyimpanan yang terlalu lama akan menyebabkan pigmen betasianin pada larutan buah bit akan mengalami degenerasi (Hidayah et al., 2016). 


\section{KESIMPULAN}

Larutan buah bit dapat dijadikan sebagai alternatif pengganti eosin $2 \%$ sebagai zat warna pada pemeriksaan telur cacing STH (Soil transmitted Helminths). Larutan yang memiliki kualitas yang yang sama dengan zat warna eosin $2 \%$ adalah larutan buah bit konsentrasi 95\%. Larutan buah bit konsentrasi 95\% mewarnai latar belakang dengan kontras, telur cacing menyerap warna dengan baik, sehingga menyebabkan morfologi telur cacing terlihat jelas dan dapat bertahan dengan baik selama 7 hari dengan penyimpanan pada suhu dingin.

\section{DAFTAR PUSTAKA}

Hidayah, N., Hadidjah, D., \& Sudjarwo, I. (2016). Ekstrak Umbi Bit (Beta Vulgaris L.) Sebagai Bahan Pewarna Plak. Beet (Beta Vulgaris L.) Tuber Extract As Plaque Staining Material. Jurnal Kedokteran Gigi Universitas Padjadjaran, 28(3), I6.

Novatama, S. M., \& Kusumo, E. (20/4). Identifikasi Betasianin Dan Uji Antioksidan Ekstrak Buah Bit Merah (Beta Vulgaris L.). Indonesian Journal of Chemmical Science, 5(3), 3-6.

Oktari, A., \& Mu'tamir, A. (2017). Optimasi Air Perasan Buah Merah (Pandanus Sp.) Pada Pemeriksaan Telur Cacing. Jurnal Teknologi Laboratorium, 6(I), 8.

Rezki, N., \& Aritonang, B. N. R. S. (20I8). Identifikasi Telur Cacing Soil Transmitted Helminth (Sth) Pada Murid Sekolah Dasar Negeri (Sdn) 91 Kecamatan Rumbai Pesisir Pekanbaru. Sains Dan Teknologi Laboratorium Medik, 3(I), I8-2I.

Subair, H., Hidayanti, H., \& Salam, A. (2019). Gambaran Kejadian Kecacingan ( Soil Transmitted Helminth ), Asupan Vitamin B 12 Dan Vitamin C Pada Anak Usia Sekolah Dasar Di Kota Makassar Overview Of The Incidence Of Helminthiasis ( Soil Transmitted Helminth ), Intake Of Vitamin B 12 And Vitamin C In E. Jurnal Gizi Masyarakat Indonesia, 8(I), I-7. 